\title{
Rediscovery of Talehsapia annandalei (Polychaeta: Pilargidae) in Songkhla Lagoon, Thailand ${ }^{1}$
}

\author{
Sergio I. Salazar-Vallejo, ${ }^{2}$ Eijirob Nishi, ${ }^{3}$ and Saowapa Anguspanicb ${ }^{4}$
}

\begin{abstract}
The pilargid polychaete Talebsapia annandalei Fauvel, 1932, has been rediscovered in its type locality and its taxonomic affinities are clarified. The genus is set off from remaining synelmins based on possession of palps completely fused and absence of tentacular cirri. The "jawlike" structure is rather a symmetrical, discontinuous pair of denticulated bands and is not a true jaw.
\end{abstract}

Fauvel (1932) Described the polychaete Talebsapia annandalei based on two specimens collected in Taleh-Sap, Thailand (Taleh-Sap means the Songkhla inner sea or lagoon). The taxonomic affinity of this taxon was enigmatic because of the presence of atypical "jaws" and the species was originally regarded as incertae sedis; it did not seem to belong to any of the then known polychaete families and it was regarded, questionably, as a very aberrant eunicid. In a later monograph Fauvel (1953) retained it as incertae sedis but closely allied to Hesionidae and more specifically related to what we now call pilargids. However, Fauvel did not accept the Pilargidae as an independent family. Hartman (1947), in contrast, did regard Pilargidae as an independent family and included Talebsapia Fauvel in her revision, but for her it was a

1 This work was partly supported by the Biodiversity Research and Training Programme in Thailand (BRT), the National Center for Genetic Engineering and Biotechnology (BIOTEC), and the Thailand Research Fund (TRF) grant 142016. Manuscript accepted 25 October 2000.

${ }^{2}$ Departamento de Ecología Acuática, El Colegio de la Frontera Sur (ECOSUR), Apartado Postal 424, Chetumal, Q. Roo 77000, México (E-mail: salazar@ecosurqroo.mx).

${ }^{3}$ Coastal Museum of Natural History, Yoshio, Katsuura, Chiba, Japan. Current address: Manazuru Marine Laboratory for Science Education, Yokohama National University, Iwa, Manazuru, Kanagawa 259-0202, Japan (E-mail: enishi@ynu.ac.jp).

${ }^{4}$ Prince of Songkla University, Hat Yai, Thailand (E-mail: asaowapa@ratree.psu.ac.th).

Pacific Science (2001), vol. 55, no. 3:267-273

(C) 2001 by University of Hawai'i Press

All rights reserved little-known genus closely allied to Loandalia Monro. In her remarks, she commented that Talebsapia differs from Loandalia in the lack of palps and the presence of jaws. This affinity with Loandalia had already been stated by Fauvel (in Mesnil and Fauvel 1939:39-40) after he rejected its original apparent affinity with euniceans and placed the genus in the Hesionidae.

In her revision of the Pilargidae, Pettibone (1966) questionably regarded Talebsapia as a junior synonym of Loandalia. Fauchald (1977:78-79) kept the taxon as incertae sedis because of its atypical jaws and even rejected, following Emerson and Fauchald (1971), its recognition as a pilargid. This problematic genus was included in the Pilargidae but regarded as being different from other pilargids by Salazar-Vallejo (1987, Salazar-Vallejo and Solís-Weiss 1992) on the basis of lack of palps and presence of jaws. Licher and Westheide (1994:225-226) thought that this genus is a member of the Pilargidae.

The original description was published 70 yr ago, and until now, no new specimens have been available to clarify this situation. The second record of Talebsapia (Fauvel 1935 ) should be ascribed to Loandalia, as Fauvel himself indicated (in Mesnil and Fauvel 1939:39-40). The original specimens may be lost; in fact, several letters are still without reply from Indian colleagues, and the loss of these specimens has yet to be confirmed. We examined the single slide deposited in the collections of the Universite Catholique de l'Ouest, Angers, and herein we present an analysis of the enigmatic features of this species on the basis of six additional specimens collected by one of us (S.A.). The pharynx has 
one pair of anterolateral glandular areas; internally, at the same level, there is a unique reinforcement structure that might explain the jawlike resemblance noted by Fauvel in the original description. The dorsal spine starts on setiger 8 , ventral cirri start on setiger 4 , and the pharynx can be 5-7 setigers in length. In most other features, the original description by Fauvel (1932) is fairly complete.

\section{MATERIALS AND METHODS}

All six specimens were collected by S.A. on 8 August 1998 in the Songkhla Lake (lagoon) $\left(7^{\circ} 29^{\prime} 17^{\prime \prime} \mathrm{N}, 100^{\circ} 24^{\prime} 34^{\prime \prime} \mathrm{E}\right)$. Sediments were sampled using a Tamura's grab (Rigosha Co., Japan, $0.05 \mathrm{~m}^{2}$ ) at $0.5-\mathrm{m}$ water depth and were mainly silty-clay or silty-clay loam. Water salinity was 24 psu (range 0-24 psu), water temperature was $33^{\circ} \mathrm{C}$, dissolved oxygen was $7.7 \mathrm{mg} / \mathrm{liter}$, and $\mathrm{pH}$ was 7.1 . The anterior region of two specimens was dissected to remove the pharynx; one pharynx was cross-sectioned close to the anterior end and the other was cut longitudinally. Reference materials are deposited in the following collections: Museum National d'Histoire Naturelle, Paris; The Natural History $\mathrm{Mu}-$ seum, London; collections of the Prince of Songkla University, Hat Yai, Thailand; Coastal Museum of Natural History, Yoshio, Katsuura, Chiba, Japan; and El Colegio de la Frontera Sur, Chetumal. The slide IEA N44', corresponding with the type specimens, deposited in the collection of the Universite Catholique de l'Ouest, Angers, was examined.

\section{RESULTS}

Two specimens were incomplete posteriorly. One of the complete ones was dissected to examine the pharynx, and an anterior fragment was also dissected. Specimens average 98 setigers (range $55-157$ ) and $27 \mathrm{~mm}$ in length $(15-52 \mathrm{~mm})$. The body has the general Loandalia-like appearance; the anterior end is swollen and there frequently are pigmented glands along the sides of the body (Figure 1a). The prostomium is rounded, anteriorly smooth, with completely fused palps and without antennae (Figures 1a-c). The fusion of palps can be detected due to a slight depression on the anterior border of the prostomium or by the longitudinal shallow furrow over the ventral side (Figure $1 d$ ). The peristomium is without tentacular cirri. The anterior swollen portion includes setigers 15. Most specimens have cerebral eyes (Figure 1c). The first parapodium is uniramous. Dorsal spines start on setiger 8 and a ventral cirrus is present from setiger 4. Notosetae consist of the emergent dorsal spine and a thin, smooth, short capillary; neurosetae consist of, up to nine per bundle, finely spinulose capillaries arranged as about half supraciculars and half subaciculars (Figure 1c). The anal plate is a slightly swollen pigmented bulb with three anal cirri; the two laterals are slightly longer than the smaller midventral one. The anus is dorsal.

The eversible pharynx is in two rings but in none of the specimens was it completely everted. The length of the everted portion is equivalent to the first four setigers. The muscular region extends over 5-7 setigers. The posterior muscular portion of the pharynx is an expanding cylinder, wider anteriorly; the proximal ring is thin with two lateral glandular areas that can be stained with rose-bengal; the distal ring is thick, heavily muscular, similar to a proventricle (Figure 2a). Internally, at the same level, there is a complex set of symmetrical, discontinuous denticulated bands at its anterior end (Figure $2 b$ ). In cross section, these bands are arranged as two curved, fusiform, oblique structures that become thinner toward their lateral joint (Figure 2c). There are a few truncated papillae pointing toward the inside of the pharynx (Figure $2 d \vec{d}$ ); the denticulated bands are rugose due to many tiny denticles (Figure 2e). These areas project posteriorly and can be seen from the outside of the body as two short, thin, darker lateral lines; if seen in cross section, they are slightly thicker or provided with more pigment.

A ventral dissection of the pharynx (Figure $3 a$ ) shows that there are two rows of alternating marginal papillae, with eight rounded papillae on the outer ring (Figure $3 b$ ), and one or two inner, distally truncated papillae (Figure $3 c$ ). The darker portions correspond 

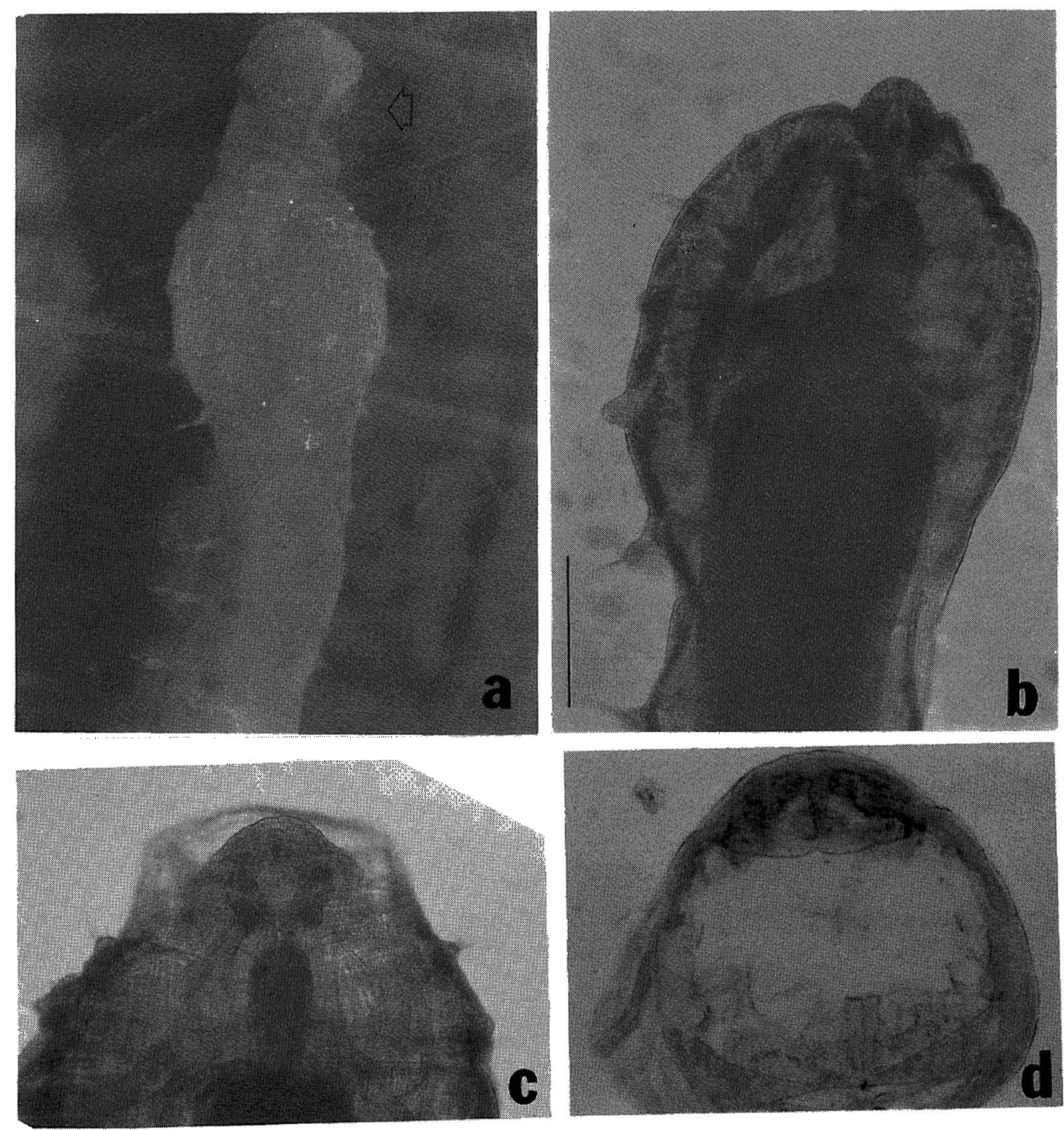

FIGURE 1. Talebsapia annandalei Fauvel. a, Anterior end of a complete specimen with the pharynx everted; note the lateral glands on the pharynx and pigmented lateral glands on the body; $b-c$, anterior end of other specimens showing its completely fused palps; $d$, cross section of a specimen showing the midventral depression on the prostomium (scales: $a, 1 \mathrm{~mm} ; b, 0.5 \mathrm{~mm} ; c, 0.3 \mathrm{~mm} ; d, 0.1 \mathrm{~mm})$.

to two groups of lateral, symmetrical, discontinuous denticulated bands that taper at both ends; each seems to be provided with a posterior projection (Figure 3c). Upon closer inspection (Figure $3 d \bar{d}$ ), the lateral bands are slightly different because the ventral one is longer than the dorsal one. They have polyhedric denticles, and over the darker adjacent areas there are other slightly wider polyhedric denticles. Some of the denticles are located over the inner margin of the band (directed posteriorly) and appear longer than the rest. 

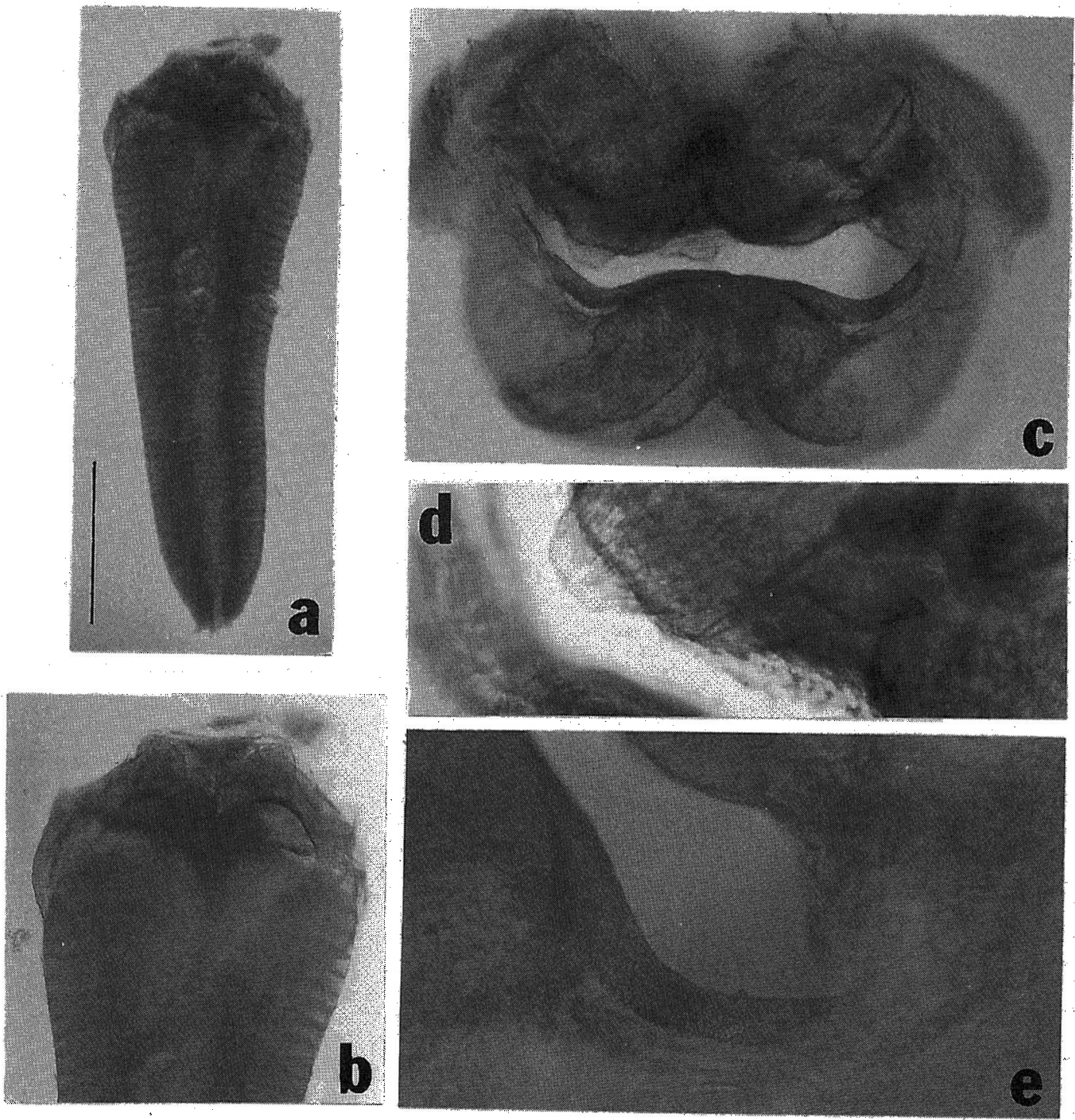

FiguRe 2. Talehsapia annandalei Fauvel. a, Dorsal view of the pharynx (dissected), widest at the anterior end; $b$, anterior end enlarged, note the laterally duplicated structures; $c$, cross section of the pharynx (ventral side is up), note the lateral discontinuity of the structures; $d$, close-up of an inner papilla showing truncated tip; $e$, close-up of the dorsal denticulated band showing tiny denticles (scales: $a, 450 \mu \mathrm{m} ; b, 270 \mu \mathrm{m} ; c, 360 \mu \mathrm{m} ; d, e, 120 \mu \mathrm{m}$ ).

The slide IEA N-44' is labeled as "Talehsapia annandalei Fauvel n. gen., n. sp., TalehSap, St. 27." It contains three parapodia but it is partly dried and because of the adsorbed salt over the setae, their fine spinulation cannot be observed. These parapodia are similar to the original illustrations by Fauvel and the ventral cirri, where present, can still be seen.

These specimens are consistent with the original description of Talebsapia annandalei Fauvel and because they come from the type locality, we consider them to belong to the 

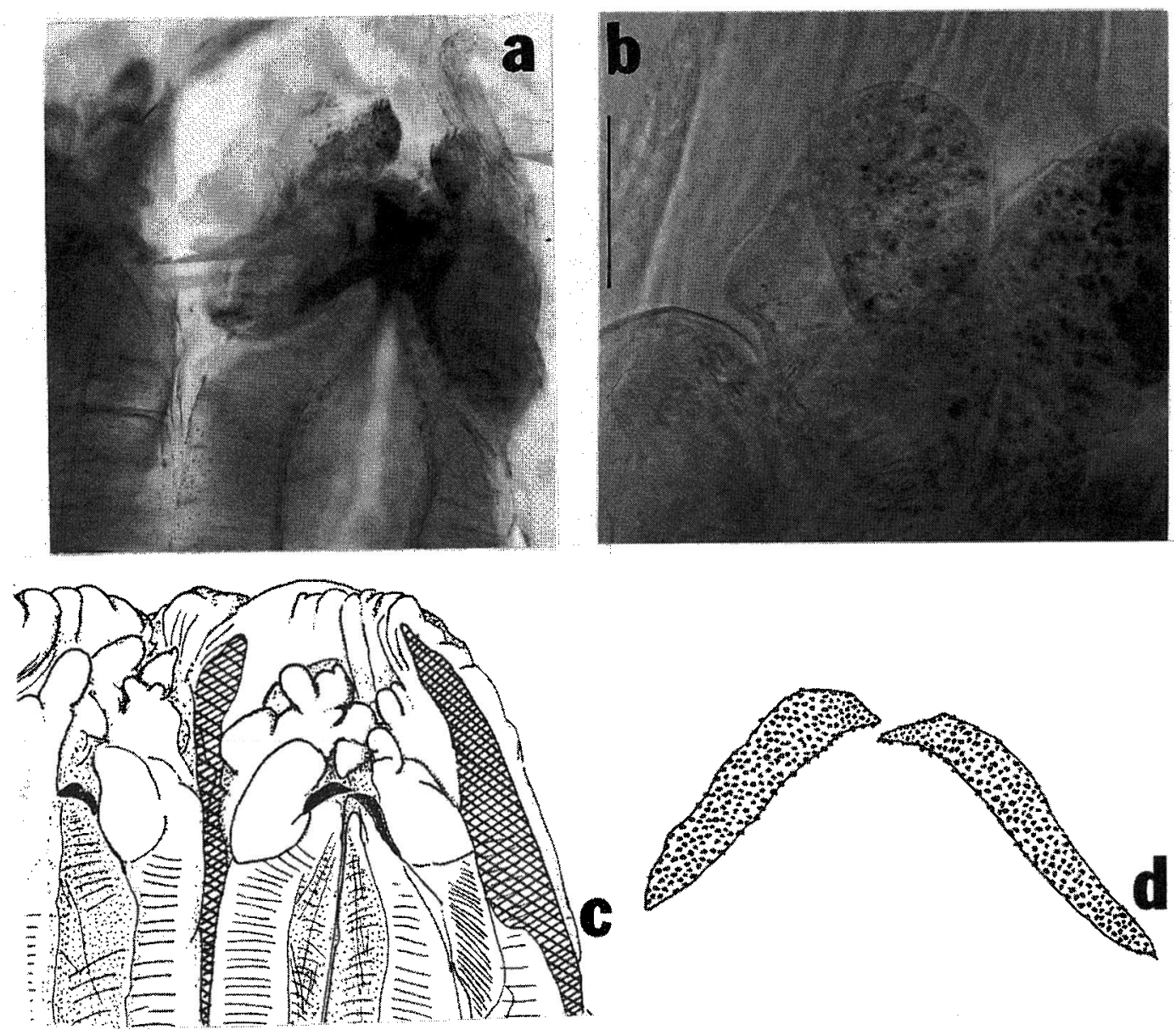

FigURE 3. Talebsapia annandalei Fauvel. $a$, Everted pharynx from Figure $1 a$, dissected ventrally; $b$, close-up of the outer midventral rounded papillae; $c$, sketch from Figure $3 a$ to illustrate the relative position and size of the denticulated bands; $d$, denticulated bands with granular appearance; the one on the right is ventral, note lateral discontinuity (scales: $a, 110 \mu \mathrm{m} ; b, 48 \mu \mathrm{m} ; c, 140 \mu \mathrm{m} ; d, 48 \mu \mathrm{m})$.

same species. This pilargid is known only from the type locality: Taleh-Sap, Gulf of Thailand (formerly Gulf of Siam). Taleh-Sap means the inner sea of Songkhla (or Singora $\left.\left[7.12^{\circ} \mathrm{N}, 100.36^{\circ} \mathrm{E}\right]\right)$. Taleh-Sap is a large estuary on the eastern side of the Malacca Peninsula, opening to the Gulf of Thailand. Associated polychaete species are Namalycastis indica Southern (Nereididae), Sigambra pukbetensis Licher \& Westheide (Pilargidae), and at least one species each in Prionospio (Spionidae), Heteromastus (Capitellidae), Cera- tonereis (Nereididae), and Nepbtys (Nephtyidae).

\section{DISCUSSION}

When working with the original material, Fauvel (1932) placed one specimen in lactic acid and compressed it, and he noticed a resistant paired structure that gave the impression of a horizontal jaw complex resembling the algebraic symbols \langle\rangle , which he regarded as a two-piece jaw. Without compression, 
however, these reinforcements are arranged as two fusiform, oblique structures that are laterally discontinuous, which explains the original observation. The pharyngeal structure of Talebsapia annandale $i$ has a slight resemblance to the trepan of syllid polychaetes (Autolytinae or Eusyllinae). Although it resembles those found in Autolytus magnus Berkeley (Imajima 1966a:41, fig. 9c), Eusyllis longicirrata Imajima (1966b:95, fig. 30b), and E. inflata Marenzeller (Imajima 1966b:100, fig. $32 b$ ), the denticulated bands of Talebsapia are different with regard to several features. In Talebsapia they are discontinuous and almost symmetrical, and the teeth are abundant and less differentiated than in the syllids. Also, they are apparently not restricted to the lateral bands of the pharynx. This may be regarded, however, as a convergent feature. The pharynx of pilargin pilargids has been described as being provided with small denticles; Pettibone (1966:179, fig. 11c) noticed that Cabira Webster has oblique rows of small denticles, and Katzmann et al. (1974:10-11, figs. $4 A, B$ ) found that Ancistrosyllis McIntosh has an irregularly denticulated band with denticles of two sizes, the dorsal being larger than the ventral ones. The symmetrical, discontinuous denticulated bands in Talebsapia seem to be unique within the family.

Talebsapia is a pilargid and thus should be assigned to the subfamily Synelminae SalazarVallejo. Its independent generic status can be recognized because of its diagnostic features: completely fused palps, lack of antennae or tentacular cirri, and presence of symmetrical, discontinuous denticulated bands in the muscular portion of the pharynx. These structures are not true jaws because they lack prominent solid structures, cusps, or any of the other salient features typically associated with jaws; thus pilargids can be regarded as jawless polychaetes.

\section{ACKNOWLEDGMENTS}

S.A. thanks A. Siripech, M. Charoenpomthip, K. Ruangnu, and J. Jailuk. E.N. thanks the staff of the Coastal Museum of Natural History, Katsuura, Japan, for their support during the work. S.I.S.-V. acknowledges the support by Consejo Nacional de Ciencia y Tecnología (CONACYT), México (32529T) and thanks H. Poupon from the Institut de Recherche pour le Développement, France; A. Crosnier and F. Pleijel from the Museum National d'Histoire Naturelle, Paris; and P. Gillet from the Université Catholique de l'Ouest, Angers. H. Bahena from El Colegio de la Frontera Sur, México, made the photographs. The critical reading by two anonymous referees and by $\mathrm{S}$. Monks improved the language.

\section{Literature Cited}

Emerson, R. R., and K. Fauchald. 1971. A revision of the genus Loandalia Monro with description of a new genus and species of pilargiid polychaete. Bull. South. Calif. Acad. Sci. 70:18-22.

Fauchald, K. 1977. The polychaete worms: Definitions and keys to the orders, families and genera. Nat. Hist. Mus. Los Angel. Cty. Sci. Ser. 28:1-188.

Fauvel, P. 1932. Annelida Polychaeta of the Indian Museum, Calcutta. Mem. Indian Mus. 12:1-262.

-. 1935. Annélides polychètes de l'Annam. Mem. Pont. Acad. Sci. Novi Lyncaei, sér. 3, 2:279-354.

. 1953. The fauna of India, including Pakistan, Ceylon, Burma and Malaya. Annelida Polychaeta. Indian Press, Allahabad. $507 \mathrm{pp}$.

Hartman, O. 1947. Polychaetous annelids, 8. Pilargiidae. Allan Hancock Pac. Exped. $10: 483-523$.

Imajima, M. 1966a. The Syllidae (polychaetous annelids) from Japan, 2. Autolytinae. Publ. Seto Mar. Biol. Lab. 14:2783.

- 1966b. The Syllidae (polychaetous annelids) from Japan, 3. Eusyllinae. Publ. Seto Mar. Biol. Lab. 14:85-116.

Katzmann, W., L. Laubier, and J. Ramos. 1974. Pilargidae (Annélides Polychètes errantes) de Méditerranée. Bull. Inst. Oceanogr. (Monaco) 71:1-40.

Licher, F., and W. Westheide. 1994. The phylogenetic position of the Pilargidae with a cladistic analysis of the taxon-facts 
and ideas. Mem. Mus. Natl. Hist. Nat. 162:223-235.

Mesnil, F., and P. Fauvel. 1939. Polychètes sédentaires de l'Expédition du "Siboga": Maldanidae, Cirratulidae, Capitellidae, Sabellidae et Serpulidae. Siboga-Expeditie 24 (2): 1-42.

Pettibone, M. H. 1966. Revision of the Pilargidae (Annelida: Polychaeta) including descriptions of new species, and redescription of the pelagic Podarmus ploa
Chamberlin (Polynoidae). Proc. U.S. Natl. Mus. 118 (3525): 155-207.

Salazar-Vallejo, S. I. 1987 (1986). Pilargidae (Annelida: Polychaeta) de México: Lista de especies, nueva especie y biogeografía. Cah. Biol. Mar. 27:193-209.

Salazar-Vallejo, S. I., and V. Solís-Weiss. 1992. Biogeography of the pilargid polychaetes (Polychaeta Pilargidae) of the subfamily Synelminae. Tulane Stud. Zool. Bot. Suppl. Publ. 1:273-283. 